$$
\operatorname{CNNF}-830942 \cdots 3
$$

UCRL- -89511

DE83 017841

\title{
DISPOSAL OF ACTIVATED FUSION WALL MATERIALS
}

\author{
J. A. Blink \\ D. W. Dorn
}

R. C. Maninger

This paper was prepared for submittal to Journal of Nuclear Materials - Special Issue Proceedings of the Third Topical Meeting on Fusion Reactor Materials, Albuquerque, NM, September 19-22, 1983.

\section{August 1983}

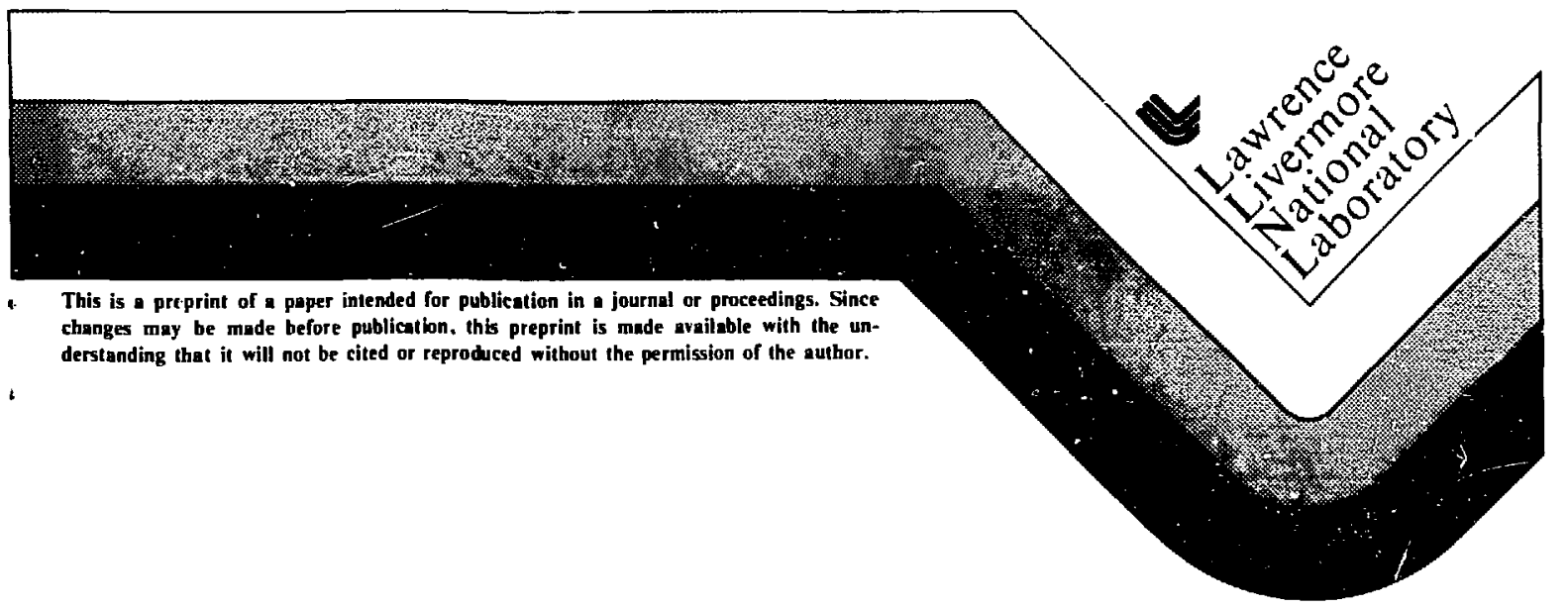

\section{MASTER}




\section{DISCLAIMER}

This report was prepared as an account of work sponsored by an agency of the Uniled States Governmenl Neither the United States Government nur any agency thereof, nor any of their employees, makes any warranty, express or implied, or assumes any legal liability or responsibility tor the accuracy, completeness, of useiulness of any information, apparatus, product, or process disclosed, or represents that its use would not intringe privately owned rights Referm eace berein to any specific commercial product, grocess, or service by trade name, trademart. manufacturer, or otherwise dues not necessatily constitute or imply its endorsement, recommendation, or favoring by the United Slates Govemment or any agency thereof. The vitws and opinions of authors expressed terein do not necessarily siate or reflect those of the United Stater Goversment or any agency theroot. 
J. A. BLINK, D. W. DORK, and R. C. MANIHGER

Lawrence Livermore National Laboratory, University of Calffornta, Livermore, California 94550

We have used NRC's lou level waste disposal regulation (10CFR61) to classffy activated fusion reactor structural materials. The 1 imits set by the ARC in 10CFR61 will require extremely expensive steels with degraded properties, even when the $11 \mathrm{mits}$ are adjusted to give credit for use of an expensive hot waste disposal facility. Both the expense and the poorer properties could have a negative impact on reactor safety, thus subverting the overall goals of the NRC family of regulations. Fullouting this inttlal study, we have examined the methodology used by the NRC to set waste concentration limits. For a long-lived gamma emitter like $94 \mathrm{Nb}$, direct ganma dose to an intruding home butlder dominates the 1 imit setting process. of a!l the tests applied to the waste, the controlling test which sets the lowest limit ignores all the engineered intrusion barriers which are themselves required by the same regulation. If even a small fraction of the barriers romain intact (an extremely 11 kely event), the $94 \mathrm{Nb} 11 \mathrm{mit}$ cou?d be increased from the $0.2 \mathrm{ct}^{3}$ in 10CFR61 to $1100 \mathrm{cl}^{3} / \mathrm{m}^{3}$ without exceeding the $11 \mathrm{~m} 1 \mathrm{ts}$ set for personnel exposure. Simtlarly, cautious application of the 10CFR61 methodelogy to other radioisotopes of interest to fusion designers will result in 1 imits which are more in line with the unique nature of fuston energy.

1. INTRODUCTION

Magnetic (MCF) and inertial (ICF) fusion reactors will produce radioactive structural and other materials through neutron activation. A major goal of current design efforts is to assure occupational and public health and safety for fusion wastes at low cost. Thus, material selection is based on both technical performance and vaste management constderations. It is 1ikely that fusion wastes will be regulated under the same institutional conditians as for fission wastes. Thus, the MRC Regulation 10CFR Part 61. "Licensing Requirements for Land Disposal of Radioactive Haste, ${ }^{1}$ is a logical starting point for examining the effects of materials selection on fusion waste management.

We belleve that the fundamental bases for 10CFR61 are excellent and pertinent to fuston as vell as fission wastes. However, some of the more detalled requirements, such as the limits for concentrations of certain specific isotopes, seem to be unrealistlc and inconsistent with the fundamental bases for 10CFR61, at least for fusion. Designers have much more freedom in controlling the character of wastes from fusion than for fisston. Fuston waste contains few if any transuranics or actinides, and it has fewer high activity elements in the fission product region. Thus, fustion waste will be more completely characterized, and surrogate nuclides need not be used to set $11 \mathrm{mits}$ for a variety of other nuclides (in contrast to the 10CFR61 procedure for fission products). Hence, ve belleve that "literal" application of the concentration 1 imits in Tables 1 and 2 of 10CFR61 is inappropriate for fuston waste and not sultable for guidance to fusion alloy developers.

The more fundamental procedures of 10CFRb1 can be used to find explicit limits of waste concentrations. To this end, we used the

- Hork performed under the auspices of the US DOE by Laurence Livermore Natlonal Laboratory under contract No. H-7405-ENG-41. 
IMVERSI and INVERSW codes ${ }^{2}$ (developed by MRC for 10CFR61) to determine the allowable concentrations of one nuclide. ${ }^{94} \mathrm{Hb}$, in fusion reactor waste. He compare our results with the 1 imit chosen by MRC and suggest that the HRC limit is overly conservative for fuston and inconsistent with the fundamental premises of 1OCFR61. Our logic can be applied to all nuclides projected to be in fusion waste. including some nuclides not explicitly considered by IOCFR61.

\section{SCENARIOS USED TO ESTABLISH CONCENTRATION LIAITS}

In 10CFR61, several scenarios are used to insure the dose to an intruder or the general public is belou set limits. These scenarios are described in Table 1 . Each scenario considers dose through one or more pathways. These include direct gamma, air (inhalation of a dust cloud, deposition on garden plants, and gama from the cloudi. food and water. Six organs and the whole body are considered, and the most restrictive limit is used.

In some cases, the scenarlos are modifled. For example, if the waste is stable, an intruder at 100 years after dump closure is assumed to recognize the waste; this reduces his exposure time from 500 hours to 6 hours. Another example is the elimination of the wind/water (but not the intruder) erosion scenarlos if the dump site is a "hot waste facility," the most expensive option in TOCFR61.

The INVERSI and INVERSW computer codes pub11shed in support of 10CFR61 can be used to determine the maximum concentration for each nuclide and scenario to $11 \mathrm{~m} 1 \mathrm{t}$ the dose to both intruders and the public. He have applied these computer codes for one nuclide of interest to fusion wall designers. ${ }^{94}$ Nb (Table 2). For long-lived nuclides 11 ke ${ }^{94} \mathrm{Hb}$ $(20,000$ year half-life $)$, regular and layered
Table 1. 10CFR61 Scenartos
Scenar 10

Intruder well

Boundary we 11

Population well

Intruder construction

Intruder agriculture

Erosion

Accident--contalner

Accident--fire

\section{Description}

A well is dug within the dump boundary 100 years after closure. It is used by the intruder.

A well at the site boundary is used by a few individuals.

A well located $500 \mathrm{~m}$ downstream from the disposal site is used by about 100 people.

An Intruder digs a 3-in-deep foundation on the dump site for his house. The loyer $1 \mathrm{~m}$ of the hole is assumed to be waste in some cases. The excavated earth is spread over a 25-mradius circle around the rouse. A family garden is planted within the circle.

After the intruder construction scenarto is cuinilete, commercial agriculture begins.

Either intruders or wind/water er ode the cover. Wind or runoff then transports the waste to population centers.

A container breaks during transportation to the dump.

Flammable waste ignites at the dump during disposal operatlons. waste is considered Class $A$ and the hot waste facility is considered class $C$ due to its 5-mthick intruder barrier. (The hot waste fact)ity is. described in more detall belou.)

2. i Implications of the $11 \mathrm{mits}$

For ferritic steels in both ICF and MCF geometries, ${ }^{94} \mathrm{Nb}$ dominates the waste at 50 years 
Table 2. Concentration Limits* $\left(\mathrm{Cl}^{3} / \mathrm{m}^{3}\right)$ for $94 \mathrm{Nb}$ in Fusion Wall-Waste Disposed in a Hot Waste Facility

\section{Scenar 1o}

Intruder well

Boundary we 11

Population well

Intruder construction

Intruder agriculture

Erosion-water

Erosion-wind

Intruder erosion-water

Intruder erosion-wind

Accident-container

Accident--fire

10CFR6 limit
Hot Waste Facility

4EB

SE 12

7E 17

1.3

1.1

none

none

4E 4

IEB

IET

none

\section{- The water scenarios use the most conservative values of the retardation coefficient. All scenarlos use waste characteristics suitable for fusion structures, and dump characteristics suitable for a hot waste factility. To allow duplication of our results, the following values of waste and dump indices are provided: flam $=0$, disp $=3$, leach $=4$, chem $=0, \operatorname{stab} 1=1$, acces $=3$ $I R=2, I D=2, I C=3, I X=1$, IE $=2, I S=1, I L=1, I G=1$, $I H=0, I C L=1, I P O=2$, III $=100$.}

after shutdown. This nuclide is produced from Nb (therma) neutron activation of natural ${ }^{93} \mathrm{Nb}$ ) and Mo (fast neutron reactions on ${ }^{94} \mathrm{Mo}$ and 95 Mo which account for $-1 / 4$ of natural Mo). If the $0.2 \mathrm{ci}^{3}{ }^{3}$ limit on ${ }^{94} \mathrm{Nb}$ is applied, Nb must be limited to $-0.6 \mathrm{wppm}$ for both ICF and MFE. ${ }^{3,4}$ The Mo limit would be $60 \mathrm{wppm}$ for MFE and $700 \mathrm{wppm}(0.07 \mathrm{wt.x})$ for ICF. ${ }^{3,4}$ If both Mo and No are present, the limits must be reduced proportionately, i.e.e

$$
\frac{C_{M_{0}}}{L_{M_{0}}}+\frac{C_{N b}}{L_{N b}}<1.0
$$

where $C$ is the concentration and $L$ is the 11 mit. These $11 \mathrm{~m} 1 \mathrm{ts}$ pose a problem for fusion wall designers. It appears to be difficult to produce any steel with Nb concentration below 10 wppm. Further, steel designers would like the freedom to include up to $1 \mathrm{w} / 0$ Mo $(10,000$ wppm) in the steel to improve its structural properties. Although the Mo limit can be circumvented by isotopically removing the worst of the seven natural isotopes, there is only one natural isotope of $\mathrm{Nb}$.

The conflict between design requirements and the locFRbl limits led us to examine the scenarios used to determine the $11 \mathrm{mits}$. Table 2 shows that for a hot waste facllity, the only significant scenarios are intruder construction and intruder agriculture.

\section{HASTE CLASSIFICATION PROCEDURE FOR THE} INTRUDER AGRICULTURE AND CONSTRUCTION SCENARIOS

Figure 1 presents the 1OCFR61 Haste Classification Test Procedure appropriate to stable waste in the intruder scenarios. This procedure ascertains the maximum allowable concentrations (11mits) in waste for nuclides of interest. Using the INVERSI code, we determined the limit for each of the tests deptcted. The tests represent increasingly expensive treatments of the waste, and thus allow near-surface disposal of wastes with increasingly higher concentrations of the radioactive 15otopes.

Before beginning the test procedure, we first must determine that the waste is physically stable and segregated from physically unstable waste. For fusion first walls, this classification is clearly true. The first test is the "Regular - Modified Test at IIC years," where IIC is the time after closure when institutional control of the dump site is lost and the site markings are assumed to be no longer recognizable. The regulation uses 100 years as 


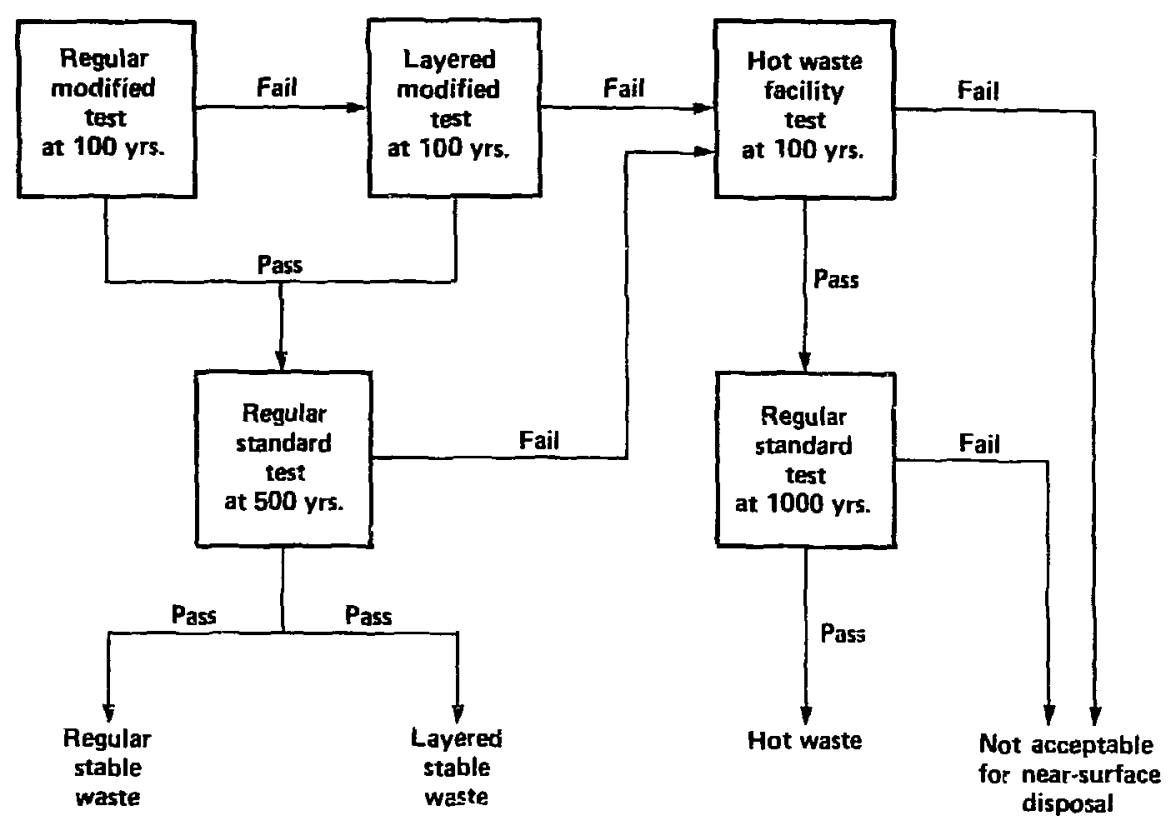

Fig. I Limit Seting Procedure for the Intruder Construction and Agriculture Scenarios.

the value of IIC. The test assumes that an inadvertent intruder begins to excavate a home foundation at the dump. After $s i x$ hours of exposure, he recognizes that he is in waste rather than earth and terminates construction. The test result is the concentration of each isotope (in $\left[1 / \mathrm{m}^{3}\right.$ ) that $w 11$ result in the maximum permissible dose to the intruder, 500 $\mathrm{mR} / \mathrm{yr}$.

The second test is the "Regular - Standard Test at 500 years." In this test, the waste is assumed to have decomposed and mixed with the surrounding earth. The intruder spends 500 hours in contact with the waste, not discerning that he is constructing his house in an old radioactive waste dump. The test assumes that the bottom $1 \mathrm{~m}$ of the 3-m-deep excavation is waste, even if thicker, engineered covers were installed at dump closure. It also gives no credit for layering the waste.
The third test, the "Layered - Modifled Test at IIC years," again assumes that the homebutlder spends six hours in the excavation before he notices that this is an old dump. However, the waste disposal site is different in that the highest activity waste has been placed at the bottom of the dump with the less active vaste above $i t$. This procedure results in the intruder being subjected to less radiation than in the "regular" (unlayered) case. Thus, the 1imit from this scenarto vill be higher than for the regular modified test

The "Hot Waste Facility Test at IIC years" assumes the waste is layered, grouted and enclosed in a concrete vault with at least five meters of "cover." The concrete vault has 1/3-m-thick concrete sides and bottom and $a$ 1-m-thick concrete top. The cover is usually an engineered barrier of clay and other materials. A final meter of fill completes the 
facility. The direct gamma pathway of the agricultural scenarto (where the homebuilder pursues commercial agriculture on the site) is not considered in the hot waste facility test. For the direct gamma pathway of the construction scenarto (where the homebutlder has a small family garden), a reduction factor of $(1 / 1200)^{2}$ is applied to account for shielding, and a factor of $1 / 100$ is applied to account for grouting and reduced accessibility. The effective removal of the radioactive waste from the biosphere by the hot waste facility results in a limit which is higher than any of the other situations.

Finally, the "Regular Test at 1000 years" assumes that the dump has had sufficlent degradation that it is indistinguishable from the surroundings. The direct gamma pathway has a reduction factor of $1 / 10$ to account for dilution during decomposition. While the additional time may allow short half-lived material to decay, the test is difficult to meet for long-lived isotopes because of the lack of discovery (500 hours of exposure during excavation), coupled with ignoring the engineered cover, the concrete vault, and the layering of the waste.
The results of applying the various intruder tests to hot waste facility waste containing 94

Nb are shown in Table 3. As Fig. 1 shows, a hot waste facility must meet only the final two tests. For ${ }^{94} \mathrm{Nb}$, the direct gama exposure is the dominant pathway for both the construction and agricultural scenarios. The regular standard test at 1000 years sets the 1imits. This test assumes that waste identity is lost and the waste is within $2 m$ of the surface (so intruders building homes excavate it). For the hot waste facility, $1 \mathrm{~m}$ of earth, $5 \mathrm{~m}$ of engineered intruder barrier, $1 \mathrm{~m}$ of concrete cap, the lower activity layers and the grout filler all are ignored in this test. Since we have assumed a hot waste facility for fusion waste, the Table $311 \mathrm{mit}$ of $1.1 \mathrm{ci} / \mathrm{m}^{3}$ 94 $\mathrm{Cl} / \mathrm{m}^{3}$.

If as 11 ttle as one meter of shielding remains intact at the time of discovery that a dump is being excavated, the dose will be more than three orders of magnitude less; 1.e., the 1 imit can be set three orders of magnitude higher, $1100 \mathrm{ci} / \mathrm{m}^{3}$. With this $19 \mathrm{mit}$, a steel containing $5 \%$ Mo and $0.4 \%$ Nb would be acceptable.

Table 3. Intruder Test Results (94Nb 11 mits in $\mathrm{Cl}^{3} / \mathrm{m}^{3}$ )

\section{Construction}

Test

Regular modified, 100 years

Layered modifled, 100 years

Regular standard, 500 years

Hot waste facility, 100 years

Regular standard, 1000 years
Direct Gamma Air Combined

103

$1.2 E 6$

1.2

2E 7

1.3

103

2EB $\quad 1.2 \mathrm{E} 6$

2E 6

1.2

2E 7

IE 7

$2 E 5$
Agr 1culture

$\begin{array}{cccc}\text { Direct gamma } & \text { Air } & \text { Food } & \text { Combined } \\ \text { none* } & \text { none* } & \text { none* } & \text { none* } \\ \text { none* } & \text { none* } & \text { none* } & \text { none* } \\ 1.0 & 6 E 6 & 1.0 & 1.0 \\ \text { none* } & \text { none* } & \text { none* } & \text { none* } \\ 1.1 & 6 E 5 & 2 E 7 & 1.1\end{array}$

* No agriculture takes place due to discovery of the waste. 


\section{SUMHARY}

The NRC has thoroughly researched pattiways. dose limits, and many other aspects of lowlevel waste disposal. NRC integrated their research into a regulation that requires barriers against inadvertent intruders who might try to use the site if it loses its identity centuries after it is filled. However, in establishing limits on waste concentrations, they set aside their mandated intruder barriers, resulting in very low limits. If the concrete cap plus at least one of the five meters of cover remains, the $11 \mathrm{mits}$ can be at least seven orders of magnitude higher.

Retaining four out of the seven orders of magnitude as a safety factor will protect intruders while giving design freedor to fusion reactor designers. Our proposed $11 \mathrm{mit}$ for ${ }^{94} \mathrm{Nb}, 1100 \mathrm{c} 1 / \mathrm{m}^{3}$, st 111 requires removal of $1 \mathrm{~m}$ of earth, and $4 \mathrm{~m}$ of engineered barrier. before an intruder would reach the NRC dose 1 1mit. Reference 2 demonstrates that natural erosion would not remove these layers daring the time of interest (1000 years). If noncorrodible engraved signs were imbedded at various depths within the barrier, it is also unlikely that an intruder would penetrate to danger ous regions.

\section{REFERENCES}

1. 10CFR61 (Fed. Register), Dec. 27, 1982.

2. Draft Environmental Impact Statement for 1OCFR61, MUREG 0782, Appendices $G$ and $H$ (Sept. 1981).

3. N. Ghoniem, J. Blink, and N. Hoffman, Selection of Alloy Steel Type for Fusion Power Plant Applications in the $450^{\circ}-500^{\circ} \mathrm{C}$ Range, presented at the Top. Conf. on Ferritic Alloys for use in Nuclear Energy Technologies (Snowbird, Utah, June 19-23, 1983).
4. F. W. Wiffen and R. T. Santoro, Control of Activation Levels to Simplify Haste Management of Fusion Reactor Ferritic Steel Components, presented at the Top. Conf. on Ferritic Alloys for use in Muclear Energy Technologies (Snowbird, Utah, June 19-23, 1983). 